Relations industrielles

Industrial Relations

\title{
Thomas J. Patten, The Managerial Challenge of Comparable Job Worth and Job Evaluation
}

\section{Esther Déom}

Volume 46, numéro 1, 1991

URI : https://id.erudit.org/iderudit/050653ar

DOI : https://doi.org/10.7202/050653ar

Aller au sommaire du numéro

Éditeur(s)

Département des relations industrielles de l'Université Laval

ISSN

0034-379X (imprimé)

1703-8138 (numérique)

Découvrir la revue

Citer ce compte rendu

Déom, E. (1991). Compte rendu de [Thomas J. Patten, The Managerial Challenge of Comparable Job Worth and Job Evaluation]. Relations industrielles / Industrial Relations, 46(1), 224-225. https://doi.org/10.7202/050653ar

Tous droits réservés @ C Département des relations industrielles de l'Universite Laval, 1991
Ce document est protégé par la loi sur le droit d'auteur. L’utilisation des services d'Érudit (y compris la reproduction) est assujettie à sa politique d'utilisation que vous pouvez consulter en ligne.

https://apropos.erudit.org/fr/usagers/politique-dutilisation/ 


\section{RECENSIONS}

\section{BOOK REVIEWS}

The Managerial Challenge of Comparable Job Worth and Job Evaluation, by Thomas J. Patten, Jr., San Francisco, Calif., Jossey-Bass Inc., 1988, 272 p., ISBN 1-55542-120-2.

Ce livre est destiné avant tout aux employeurs américains. Comme le mentionne l'auteur lui-même, il a adopté une perspective administrative afin de sensibiliser les employeurs du secteur privé américain au défi que représente l'implantation de l'équité salariale pour les organisations. Il veut lui faire prendre conscience que l'équité est devenue une réalité dans un large segment du secteur public et que le secteur privé devra bientôt emboîter le pas.

L'auteur commence (chap. 1), comme tout bon universitaire, par définir les différentes notions de travail égal, similaire, équivalent afin de bien situer la notion d'équité salariale. Il présente les points de vue pro et anti-équité, il fournit les statistiques habituelles sur la participation des femmes au marché du travail et explique brièvement les outils (régressions) utilisés pour mesurer l'iniquité salariale. Enfin, il résume très brièvement l'histoire du mouvement féministe. Ce premier chapitre a comme objectif de situer le problème (puisque c'en est un pour la plupart des organisations) et à cause de la diversité des sujets traités, il manque un peu d'unité.

Le chapitre 2 présente le matériel juridique essentiel pour comprendre les obligations des employeurs et la position actuelle des tribunaux américains sur la question du travail équivalent. On y retrouve entre autres une discussion du cas désormais célèbre (le cas «Gunther») et des cas qui ont été débattus devant les tribunaux par la suite. On observe ainsi, depuis le cas Gunther, une tendance des tribunaux de différents niveaux à rejeter les plaintes de travail équivalent à moins que les plaignantes puissent prouver l'intention de discriminer et puissent établir le motif de discrimination. L'argument du marché est considéré comme une raison professionnelle justifiant de maintenir des écarts salariaux même à travail équivalent.

L'auteur poursuit (chap. 3) en présentant un éventail d'expériences d'implantation de l'équité salariale dans le secteur public américain (États et municipalités). Ceci l'amène à conclure sur les coûts raisonnables requis pour implanter l'équité salariale.

Le chapitre 4 traite de la négociation de l'équité. Là aussi, l'auteur choisit d'illustrer son propos en racontant l'histoire de deux grèves importantes. Il explique pourquoi et comment les syndicats se sont impliqués dans ce domaine et suggère aux employeurs certains comportements pour qu'ils puissent s'adapter et développer des positions de négociation. Même si l'auteur affirme à plusieurs reprises son parti pris en faveur de l'équité salariale, on est mal à l'aise quand il étale et discute certains trucs que l'employeur peut utiliser soit pour mettre le syndicat sur la défensive ou créer des dissensions internes, soit pour se prémunir contre l'intervention, toujours possible, des tribunaux. Même si l'auteur qualifie lui-même ces trucs de dirty tricks, il en traite juste assez pour donner des idées à certains employeurs.

Les deux chapitres suivants traitent de l'évaluation des emplois et de son utilisation pour l'équité salariale. Il passe ainsi en revue les différentes méthodes quantitatives et non quantitatives d'évaluation et choisit de s'attarder au plan Hay utilisé pour l'implantation de l'équité salariale dans l'état d'Idaho. 
Le livre se termine par une discussion des stratégies patronales possibles pour l'implantation de l'équité.

Ce livre est constitué comme un dossier qui présente aux employeurs ce qu'ils doivent absolument savoir avant de s'embarquer dans un processus d'implantation de l'équité salariale. À ce titre, et compte tenu des particularités des lois américaines, il ne peut vraiment servir qu'aux employeurs américains, sauf peut-être les chapitres 5 et 6 qui sont plus techniques et qui traitent de l'évaluation des emplois dans le contexte de l'équité. On peut cependant déplorer à ce sujet l'exemple retenu par Patten (le plan Hay): on n'y retrouve pas certains facteurs (par exemple, la simultanéité des tâches) reconnus comme caractéristiques de beaucoup d'emplois féminins. Ce qui devrait inciter à la prudence dans la considération de plan semblable pour l'atteinte de l'équité salariale. Enfin, l'auteur ne traite pas de l'impact important de l'organisation du travail sur les écarts salariaux: il considère que la rémunération à la performance par exemple, est compatible avec la notion de travail équivalent (p. 2).

En résumé, ce livre pourra sans doute être utile aux employeurs américains à qui il est destiné de toute façon mais il comporte certaines lacunes qui découlent d'une définition étroite de la discrimination et qui nous amènent à nous interroger sur le standard d'équité qui y est véhiculé.

Esther DÉOM

Université Laval

Comparable Worth: Analyses and Evidence, edited by M. Anne HiLl and Mark R. Killingsworth, Ithaca, ILR Press, New York State School of Industrial and Labour Relations, Cornell University, 1989, 138 p., ISBN 0-87546-147-6. - ISBN 0-87546-148-4 (pbk.)

With all jurisdictions in Canada, except for the three Western provinces, having some form of pay equity legislation (i.e., equal pay for work of equal value), there should be considerable interest in quality research on the topic. This volume, which is the product of a colloquium held at Rutgers University in 1987, is an important contribution in that regard.

The colloquium was an "all-star" cast of paper writers and discussants, from a number of disciplines, albeit economists tended to dominate. The papers were a judicious blend of theory and policy analysis, as well as empirical evidence, usually with due attention paid to the existing literature. In fact the summaries of the relevant theoretical and empirical literature on different aspects of the topic, were extremely useful.

The first paper, by Mark Aldrich and Robert Buchele, examined the implications of efficiency wages for comparable worth. (Comparable worth is the term used in the United States for equal pay for work of equal value.) Efficiency wages refer to wages paid above the competitive norm. They have an efficiency rationale in that they may improve effort, morale, commitment, loyalty and productivity, and they may reduce turnover, shirking and conflict. Efficiency wages will tend to be paid in jobs where these attributes are important, for example where turnover costs are high. Women may be excluded from such jobs because of discrimination or because of a perception that they may have greater turnover. The authors provide empirical evidence from the U.S. indicating that the greatest potential for comparable worth is in industry that pay large wage premiums. They also indicate, however, that there are few women in those sectors to benefit by a comparable worth policy that compels the sharing of those wage premiums. 